\title{
Method based on life cycle assessment and TOPSIS to integrate environmental award criteria into green public procurement
}

Rosario Vidal*, Núria Sánchez-Pantoja

Department of Mechanical Engineering and Construction, GID, Universitat Jaume I, Av. Sos Baynat s/n, 12071 Castellón, Spain

*Corresponding author: Rosario Vidal. Email address: vidal@uji.es

\begin{abstract}
Green public procurement (GPP) aims to integrate environmental criteria into public tender as instrument to develop and encourage production and consumption of sustainable products and services. Inclusion of award criteria in GPP is a key factor of its success. To this aim, a new method for assessing environmental award criteria in GPP processes is introduced in this study, providing easy and effective communication of the environmental benefits of the products and services purchased. The method is intended for its use by public authorities and companies. The main novelty of the method lies in its ability to evaluate the achievement of each award criterion during the GPP process using a simplified life cycle assessment methodology and a further simplification of the environmental indicators in one score using TOPSIS. This method is applied to public procurement of urban furniture as a case study.
\end{abstract}

\section{Highlights}

- A method based on LCA and TOPSIS is presented to evaluate award criteria.

- Environmental benefits are easily and effectively communicated.

- The method is applied to the green public procurement of urban furniture. 
- Compulsory and award criteria for urban furniture are defined.

\section{Keywords}

Green Public Procurement; urban furniture; TOPSIS; life cycle assessment; award criteria

\section{Introduction}

Green Public Procurement (GPP) is a powerful instrument to develop and encourage the production and consumption of sustainable products and services. In Europe, efforts to support GPP have gradually increased in order to reduce environmental impacts from a full life-cycle perspective (Bratt, Hallstedt, Robèrt, Broman, \& Oldmark, 2013). As the European Commission (EC) consider Europe's public authorities as major consumers, using their processes for purchasing goods, services, and works in a more environmentally sustainable manner can make an important contribution to sustainable consumption and production. GPP is a voluntary instrument and a stimulus for eco-innovation. However, it is difficult to implement and requires a large amount of effort from public administrations.

The development and research of GPP have increased notably since 2000, which is when debate on this topic in literature began, although most papers in this subject area have been published in the last six years (Cheng, Appolloni, D'Amato, \& Zhu, 2018). Much of the discussion is focused on environmental policy implementation, especially for specific sectors and areas, and few theoretical studies have been conducted to assess GPP as an environmental policy instrument and further assess the impacts of the environmental criteria (Cheng et al., 2018; Lundberg \& Marklund, 2012, 2018). The EC has promoted the implementation of GPP principles in all Member States through the development of GPP criteria for over 20 purchasing areas, including 
construction, transport, and textiles, since 2008 (Rainville, 2017). However, such principles have not been applied to other areas, such as urban furniture.

Many factors influence the development of GPP practices among public authorities. However, Testa et al. (2016) concluded that awareness and knowledge of GPP techniques and procedures are the most relevant factors, having a much greater influence than the availability of economic resources and budget flexibility, which are typically considered more often. Their study highlighted the need to establish useful guidelines or toolkits and to conduct effective training activities. The aim of this is to integrate environmental criteria into public tenders and train employees to evaluate products or services in a sustainable manner, as they already do for price or quality.

Decision-making in GPP requires understandable and clear environmental assessment methods. Life cycle assessment (LCA) methods have gained significant influence, although their direct use as LCA-based criteria is limited (Parikka-Alhola \& Nissinen, 2012), and it would be advisable to extend the LCA approach to other instruments and resources. The sustainability of the built environment will be enhanced as the use of multi-objective optimization methodologies for the implementation of LCA studies increases (Kylili \& Fokaides, 2017).

There is a debate about the use of midpoint, endpoint, or single-score indicators in LCA for supporting the decision-making process (Kägi et al., 2016; Pizzol et al., 2017). Detailed descriptions of various weighting approaches have been presented in the literature (e.g. Huppes et al., 2012; Pizzol et al., 2017). Midpoint indicators present impact potentials based on scientifically sound methods. However, endpoint methods create additional uncertainty as their modeling of impact pathways is more complete, and this should be considered when comparing 
impact categories. The midpoint approach also serves as an intermediate step in an endpointoriented method (Goedkoop, Heijungs, De Schryver, Struijs, \& van Zelm, 2013). Subjective weighting is used for single-score aggregation; therefore, the ISO 14044:2006 only recommends the use of a sufficiently comprehensive set of midpoint impact indicators when disclosing comparative assertions to the public (ISO, 2006).

Despite the risks associated with using less scientific results, the demand for LCA-based policy development, and hence simplified communication, is increasing (Kalbar, Birkved, Nygaard, \& Hauschild, 2016; Pizzol et al., 2017). Weighting is important to present these environmental impacts in a comprehensible manner (Ahlroth, Nilsson, Finnveden, Hjelm, \& Hochschorner, 2011). There are many approaches to weighting the results of LCA on midpoint and endpoint levels, and the most common principles include the evaluation of impacts/damages in monetary terms, such as BEES (Lippiatt, 1999) and TRACI (Bare, 2002); the distance-to-target (DTT) approach, such as EDIP 97 (Wenzel \& Hauschild, 1998), ecological scarcity (Frischknecht, Steiner, \& Jungbluth, 2009), and DTT for Europe 2020 (Castellani, Benini, Sala, \& Pant, 2016); and panel weighting, such as Ecoindicators 99, ReCiPe 2008 (Goedkoop et al., 2013; Myllyviita, Leskinen, \& Seppälä, 2014). Pizzol et al. (2017) critically investigated modern normalization and weighting approaches within LCA and concluded that weighting the damage was preferable to weighting the distance to a target.

Simple linear weighted sum (LWS) is the most frequently used method for obtaining single scores, such as ReCiPe single-score (Goedkoop et al., 2013). LWS presents some problems associated with the single-score calculation approach, as it does not consider either the effect of so-called 
dominating alternatives (i.e., alternatives with high values across all endpoints) or the interdependency of the indicators being aggregated (Kalbar et al., 2016; Pizzol et al., 2017).

Other, more complex multi-criteria decision-making methods (MCDM) have emerged as alternative approaches for obtaining single scores (Pizzol et al., 2017; Seppälä, Basson, \& Norris, 2001). The analytical hierarchy process (AHP) has been employed to develop weighting values for use in LCA interpretation by a panel of experts (Hafizan, Noor, Abba, \& Hussein, 2016; Myllyviita et al., 2014). The AHP approach compares alternatives or criteria based on an attribute or pairwise comparison. A scale of absolute importance using numbers that describe individual preferences towards quantitative and qualitative attributes is adopted to achieve this (Saaty, 1990).

The Technique for Order of Preference by Similarity to Ideal Solution (TOPSIS) is another popular method of multi-criteria decision analysis (Hwang \& Yoon, 1981), which compares a set of alternatives by calculating the distance from each alternative to the positive ideal alternative (best in each dimension) and negative ideal alternative (or worst) through the defined dimensions using one of several possible distance measures (such as Euclidean distance). The ratio between the distance (separation) from the negative ideal solution and the sum distance between the ideal and negative ideal alternative solutions is calculated and used to calculate alternatives. The benefits of TOPSIS over other MCDM include the avoidance of judgments, while relative distances depend on the range of alternatives themselves, and the non-linear relationship between single dimension scores and distance ratios, which produces smoother tradeoffs (Amine, Pailhes, \& Perry, 2014; Huang, Keisler, \& Linkov, 2011; Salmeron, Vidal, \& Mena, 2012). In addition, the TOPSIS approach performs better than the LWS in the single score calculation of LCA (Kalbar et al., 2016). 
This study proposes a distance LCA-based multiple criteria decision-making method for obtaining single scores to evaluate award criteria for green public procurement. The main novelty of the method lies in its ability to evaluate the achievement of each award criterion during the GPP process using the simplified LCA methodology and the further simplification of the LCA indicators in one score using TOPSIS. This method is applied to the GPP of urban furniture as a case of study. The document is structured as follows: section 2 completes the introduction with a review of GPP tools and presents the new method, section 3 explains the new method applied to urban furniture, section 4 analyzes the values obtained by each criterion (applied to the case study), the limitations of the method, and its future scope, and the conclusions are then presented.

\section{Methodology}

There are several environmental assessment methods and tools (Deakin \& Reid, 2014), some of which may support GPP in different products and services. These can be classified according to the categorization of tools for sustainable design (Gowri, 2005):

- Knowledge-based tools, including manuals and information sources that serve as reference materials for designers. For the general purpose of GPP in Europe, the reference knowledge-based tool is the Handbook and the GPP Toolkit published by the European Commission (2016), complemented with specific green criteria (for furniture, see European Commission, 2017). This type of tool can aid in defining the compulsory and award criteria, but it does not offer the support to score each award criterion.

- Performance-based tools. Life cycle impact assessment tools are included in this category (for a review, see Rossi, Germani, \& Zamagni, 2016; Rousseaux et al., 2017). Tools to 
perform a complete LCA (as SimaPro or Gabi) require skilled practitioners to use them (Rossi et al., 2016), which is not the case for many GPP practitioners. Simplified LCA tools (such as Simple Minds or Quantis Suite) present simplifications at different levels, such as input data, calculation methods, and the graphics interface. These generic tools are more user-friendly, although they are still unsuitable for GPP practitioners. A few performancebased tools for public purchasing have been developed to assess the environmental impacts of purchases; however, they are rarely used in real purchases (reviewed by Parikka-Alhola \& Nissinen, 2012). Carbon footprint tools (Cerutti, Contu, Ardente, Donno, \& Beccaro, 2016; Mattinen \& Nissinen, 2012) that only include one impact category are also included in this category.

- Rating tools. This category includes design checklists and credit rating calculators that were developed to assist designers in identifying design criteria and documenting the performance of the proposed design. The most well-known building rating tools for urban environments are LEED (Leadership in Energy and Environmental Design) and BREEAM (Building Research Establishment Assessment Method) (Doan et al., 2017; Fenner \& Ryce, 2008), both of which are credits-based systems where a building is given credits for achieving particular performance targets under headings such as energy, indoor environmental quality, and water efficiency. BREEAM and LEED have enabled the building industry to evaluate construction projects in an accessible manner, although both systems lack consistency (Fenner \& Ryce, 2008). Envision ${ }^{\text {TM }}$ is a novel rating system for a variety of infrastructure projects, and has been applied to public bike-sharing (Trop, 2018). Although 
all of these tools may be used to certify materials, they are not directly appropriate for any kind of GPP.

The performance-based method proposed in this paper takes the award criteria from knowledgebased tools (European Comission, 2016; European Commission, 2017b) and assesses them based on a simplified LCA (performance-based tools). The LCA indicators are simplified in one score using TOPSIS. The method is developed in a software tool that should be accessible for GPP practitioners (LIFE FUTURE, 2018).

The procedure of the proposed method to assess green criteria for GPP is expressed in the following nine steps, Figure 1:

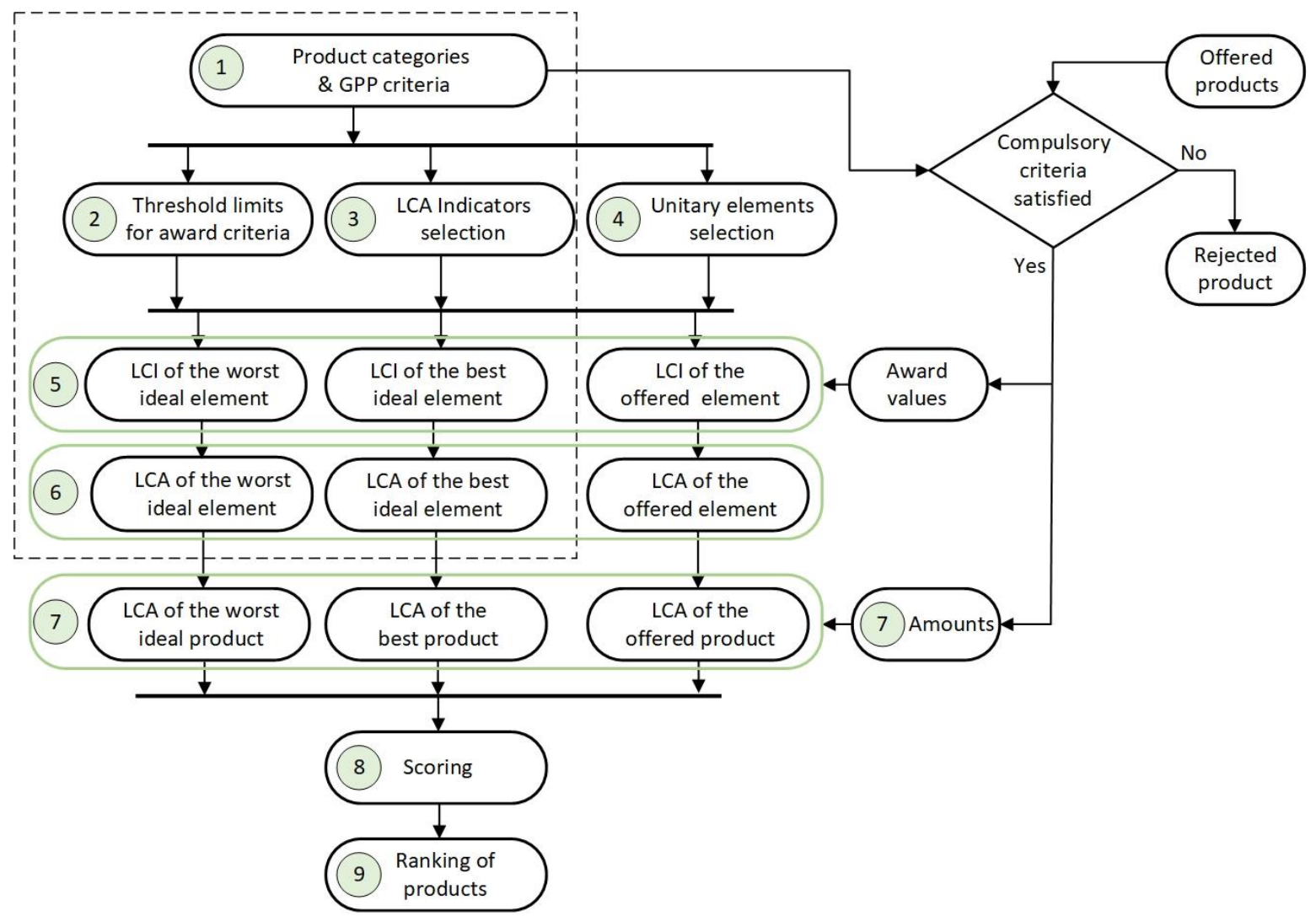

Figure 1. Methodological proposal. Dashed line is the common system for all urban furniture products 
Step 1: Product categories and criteria for GPP

Compulsory and award criteria are selected for the product categories to be assessed. All compulsory criteria must be satisfied before environmental scoring with the award criteria is conducted.

Step 2: Threshold limits for award criteria

Based on the current state of the technology, establish the threshold limits (worst and best) for each award criterion.

Step 3: LCA indicators

Select the $m$ LCA indicators for scoring.

Step 4: Selection of elements

Select the $k$ unitary elements to decompose all the product categories to be analyzed.

Step 5: Life cycle inventories for unitary elements

The unitary elements are defined with three alternatives: the worst, the best, and the bidder. The same life cycle inventory ( $\mathrm{LCl}$ ) of both the worst (default values) and best options are configured for all the bidder choices. The parameters given for each award criterion by each bidder are included in the $\mathrm{LCl}$ of the bidder's elements.

Step 6: Life cycle assessment of unitary elements

LCA indicators are obtained for the worst and best alternative of each element, $E_{k m^{-}}$and $E_{k m}{ }^{+}$, respectively, while LCA indicators are dynamically obtained for the bidder's elements.

Step 7: Life cycle assessment 
LCA indicators for each product, $i$, in the three alternatives (the worst, best, and the bidder, $x_{i m}{ }^{-}$, $x_{i m}{ }^{+}$, and $x_{i m}$, respectively) are obtained from the sum of each element indicator multiplied by its amount or physical weight, $w_{i k}$.

$$
\begin{aligned}
& x_{i m}^{-}=\sum_{k} w_{i k} \cdot E_{k m}^{-} \\
& x_{i m}^{+}=\sum_{k}^{k} w_{i k} \cdot E_{k m}^{+} \\
& x_{i m}=\sum_{k} w_{i k} \cdot E_{k m}
\end{aligned}
$$

Step 8: Scoring

A score of 0 is assigned to the worst alternative and a score of 100 is assigned to the best. No negative values are possible. Therefore, the score for each product is calculated using the Euclidean distance of the ratio between the distance from the worst ideal alternative and the distance from the best and worst ideal alternatives.

$$
x_{i}=\frac{100}{\sqrt{m}} \cdot \sqrt{\sum_{m} \frac{\left(x_{i m}-x_{i m}^{-}\right)^{2}}{\left(x_{i m}^{+}-x_{i m}^{-}\right)^{2}}}
$$

Step 9: Ranking products

A set of alternatives can then be ranked by preference according to the descending score, or the score value can be weighted and added to the economic bid.

\section{Study Case: Urban furniture}

The proposed method is implemented in the EU project "LIFE FUTURE" for the GPP of urban furniture, which is explained below. The online GUF TOOL application (GUF is the acronym for Green Urban Furniture) can be freely accessed (LIFE FUTURE, 2018). 


\subsection{Product categories and criteria for GPP}

The concept of urban furniture is very broad and can cover any type of object or facility that we would usually find in our cities. To limit and classify street furniture for this case study, related literature were reviewed (Grove \& Cresswell, 1983; IHOBE, 2014; Paryabi, 2015; Pianoo, 2015). A list of the most representative elements of urban furniture is established according to their functionality, without those elements that require energy to be used. The list includes benches, seats and chairs, bicycle parking, canopies and kiosks, bins and containers, information panels, planters and pots, tree pits and lids, playgrounds, sport courts, showers and footbaths, fountains and hydrants, traffic signs, guardrails and barriers, milestones and bollards, and speed reducers.

Table 1. Environmental compulsory criteria for urban furniture

\begin{tabular}{|c|c|c|}
\hline Code & Criteria name & Brief explanation \\
\hline $\mathrm{C} 1$ & Legal origin of wood & $\begin{array}{l}\text { All wood materials shall come from legally sourced timber in accordance with } \\
\text { Regulation (EU) } 995 / 2010 \text {. If not, timber should be either covered by FLEGT licenses, } \\
\text { covered by CITES licenses or equivalent. }\end{array}$ \\
\hline $\mathrm{C} 2$ & $\begin{array}{l}\text { Preservatives in } \\
\text { Wood }\end{array}$ & $\begin{array}{l}\text { Wood classified with a durability class of } 1 \text { or } 2 \text { (EN 350) or equivalent must not have } \\
\text { been treated with preservatives. Other classes of wood must not have been treated } \\
\text { with substances classified according to Regulation (EC) No 1272/2008 of the European } \\
\text { Parliament and of the Council. }\end{array}$ \\
\hline C3 & $\begin{array}{l}\text { Formaldehyde } \\
\text { emissions of wood- } \\
\text { based panels }\end{array}$ & $\begin{array}{l}\text { Wood-based panels, which were manufactured using formaldehyde-based resins, } \\
\text { shall have equal to or less formaldehyde emission levels than the E1 threshold limits } \\
\text { as defined in Annex B of EN } 13986 \text {. }\end{array}$ \\
\hline $\mathrm{C} 4$ & Surface coating & $\begin{array}{l}\text { The products used for surface coating shall not be classified according to Regulation } \\
\text { (EC) No } 1272 / 2008 \text { of the European Parliament and of the Council. }\end{array}$ \\
\hline C5 & $\begin{array}{l}\text { Cadmium and nickel } \\
\text { restrictions }\end{array}$ & $\begin{array}{l}\text { Cadmium shall not be used for electroplating operations of any metal component } \\
\text { parts used in the final furniture product. Nickel shall only be permitted in } \\
\text { electroplating operations if the nickel release rate from the electroplated component } \\
\text { part is less than } 0.5 \mu \mathrm{g} / \mathrm{cm} 2 / \text { week according to EN } 1811 \text {. }\end{array}$ \\
\hline C6 & $\begin{array}{l}\text { Reach candidate list } \\
\text { restrictions }\end{array}$ & $\begin{array}{l}\text { The presence of any REACH Candidate List substances in the product and any } \\
\text { component parts/materials thereof shall be declared. Besides, these substances shall } \\
\text { not be present at a concentration of greater than } 0.1 \% \text { (weight by weight). }\end{array}$ \\
\hline $\mathrm{C7}$ & Fitness for use & $\begin{array}{l}\text { The furniture product shall comply with the requirements set out in the latest versions } \\
\text { of the relevant EN standards or other equivalent that may relate to the durability, } \\
\text { dimensional requirements, safety and strength of the product. }\end{array}$ \\
\hline
\end{tabular}




\begin{tabular}{lll}
\hline Code & Criteria name & Brief explanation \\
C8 & $\begin{array}{l}\text { Specific } \\
\text { characteristics for } \\
\text { packaging }\end{array}$ & $\begin{array}{l}\text { Optimized design to reduce the use of raw materials is required. } \\
\text { Materials must consist of recycled materials and/or ones taken from renewable } \\
\text { resources, and/or biodegradables, or be a multisystem. } \\
\text { Elements shall be easily separable by hand into recyclable parts of one material (e.g. } \\
\text { cardboard, plastic). }\end{array}$ \\
\hline \multirow{3}{*}{ C9 } & $\begin{array}{l}\text { Design for } \\
\text { disassembly and } \\
\text { repair }\end{array}$ & $\begin{array}{l}\text { Clear disassembly and repair instructions to enable a non-destructive disassembly of } \\
\text { the furniture product for the purpose of replacing component parts/material should } \\
\text { be provided by tenderers. }\end{array}$ \\
C10 & $\begin{array}{l}\text { Warranty and } \\
\text { replacements }\end{array}$ & $\begin{array}{l}\text { Three-year warranty effective shall be provided, cover repair or replacement and } \\
\text { include a service agreement. } \\
\text { Manufacturer shall be also required to keep in stock, for a period of at least } 3 \text { years, } \\
\text { compatible replacements for the expendable parts of the product. }\end{array}$ \\
\hline
\end{tabular}

The selection of more sustainable products is not a trivial task and it can be made more complicated by several factors (Cordella \& Hidalgo, 2016). A literature review was conducted to determine the most relevant criteria in the adoption of GPP (Cordella \& Hidalgo, 2016; European Commission, 2017b; ICLEI, 2013; Pianoo, 2015; Umweltbundesamt, 2013; US EPA, 2016).

Several eco-design methodologies support the design of environmentally sustainable products (Rossi et al., 2016). Eco-Design Wheel or Wheel LIDS (Brezet \& Hemel, 1997), which allows the development of more sustainable strategies than other products existing on the market, was selected to complete the criteria and improve their visualization. The categories of environmental strategies are distributed along each of the eight axes of Eco-Design Wheel. Axis 1 corresponds to the selection of low-impact materials, such as clean, renewable, and recycled materials.; axis 2 promotes the reduction of materials; axis 3 includes strategies to optimize production; axis 4 collects strategies to optimize the distribution; axis 5 presents the strategies to reduce impacts during usage; axis 6 includes strategies to optimize the product's lifespan; axis 7 focuses on endof-life optimization through reuse, recycling, or recovery; and axis 8 promotes the development of new concepts geared towards dematerialization and sharing. Eco-Design Wheel was previously 
used for ranking alternatives in other methodologies (Chulvi \& Vidal, 2011; Vidal, Salmeron, Mena, \& Chulvi, 2015).

The selected environmental criteria are grouped into compulsory (Table 1) and award or voluntary criteria (Table 2), which give the product its final environmental score, ranging from 0 to 100 . The criteria are shown in Figure 2.

Figure 2. Environmental criteria for green public procurement. Award criteria are grouped into the axis of the EcoDesign Wheel (Brezet \& Hemel, 1997)

\section{ENVIRONMENTAL CRITERIA}

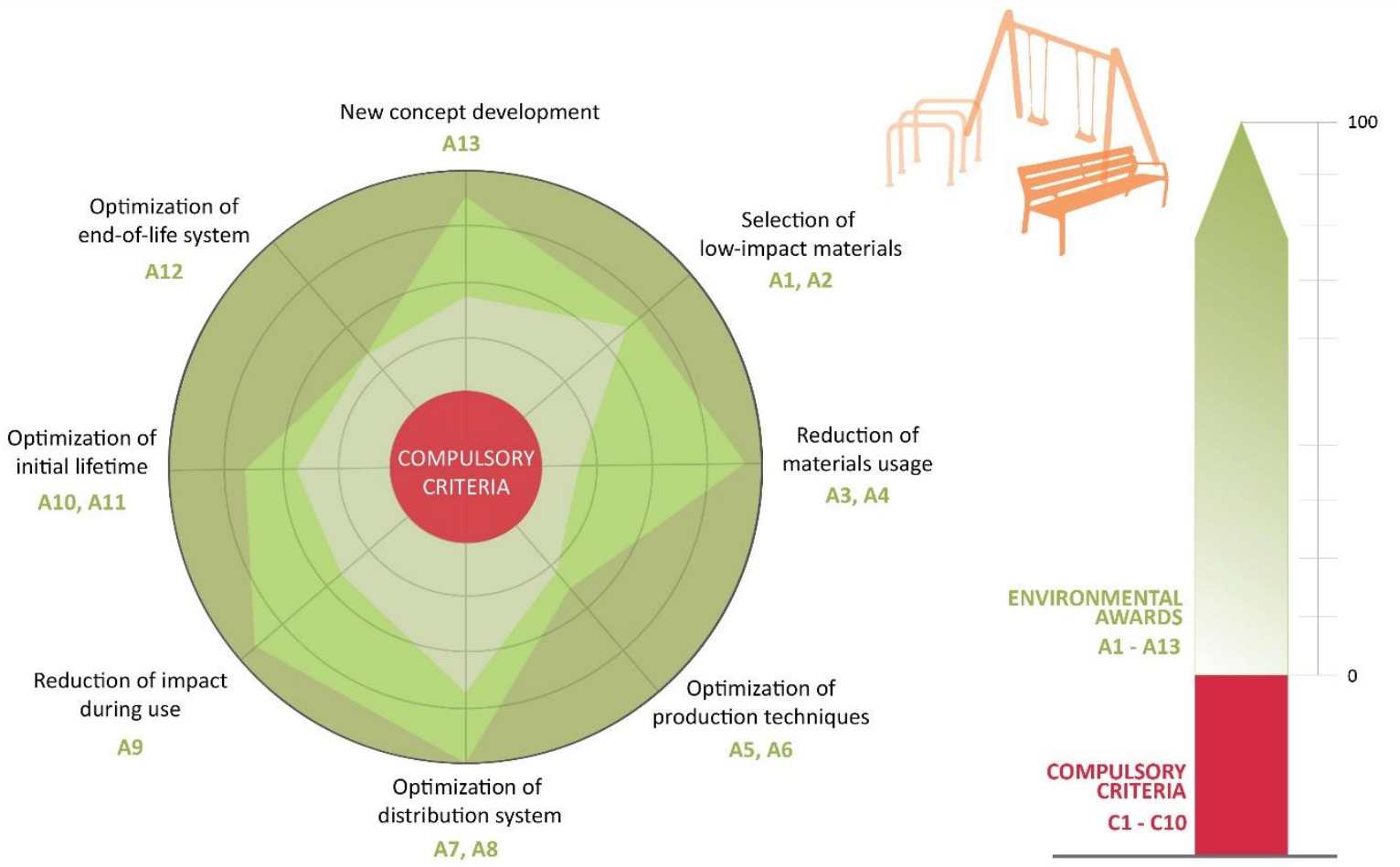

\subsection{Threshold limits for award criteria}

Award criteria are developed to give the final product a score that allows it to be compared to others from an environmental viewpoint. However, it was necessary to define an acceptable 
range of values for each of the criteria owing to their distinct characteristics. Threshold limits for each award criterion are listed in Table 2.

As these criteria are applicable to all materials, the percentage of recycled or reused materials $(A 1)$, renewable energy used (A5), and potential for recovery or recuperation ( $A 12)$ may range from 0 (default value) to $100 \%$. The maximum percentage of weight $(\mathrm{A} 3)$ and volume (A4) reduction resulting from improved product design is estimated to be $10 \%$. Products with higher percentages, which might be the result of improved materials or a complete redesign, would be taken as a new product, and the corresponding reduction of impacts is associated with the new design.

A revision of statistical values on the impact of freight transport in Europe allowed us to simplify the entry of data according to whether the materials originated (A2) from local (less than 100 $\mathrm{km})$, European, or outside-Europe sources (European Commission, 2017a). The distance from the manufacturing to the construction site (A7) is given a value between 0 and $1000 \mathrm{~km}$, with 1000 $\mathrm{km}$ being the default value for lorry-based transport according to Environdec (The International EPD System, 2018).

The reduction of energy consumption $(A 6)$ is calculated from the standard value of the industrial sector, regardless of whether renewable energy sources are used or not, and is given a maximum value of $20 \%$. Consumables in urban furniture (A9) range from small pieces that may need to be replaced during the lifetime of the product, to paints or varnishes that must be applied to the product on a regular basis. The reduction of this maintenance work for a street furniture product could reach $100 \%$. 
Table 2. Award criteria and threshold limits for urban furniture

\begin{tabular}{llll}
\hline Code & Criteria & Lowest & Highest \\
\hline A1 & \% Recycled / \% reused materials & 0 & 100 \\
A2 & Origin of raw materials (transport) & Outside Europe & Local (less than $100 \mathrm{~km}$ ) \\
A3 & Weight reduction by product design (\%) & 0 & 10 \\
A4 & Volume reduction by product design (\%) & 0 & 10 \\
A5 & Use of renewable energy (\%) & 0 & 100 \\
A6 & Energy consumption reduction (\%) & 0 & 20 \\
A7 & Distance from manufacturing to construction site (km) & 1000 & 0 \\
A8a & Recycled materials in packaging (\%) & 0 & 100 \\
A8b & Origin of raw materials in packaging (transport) & Outside Europe & Local (less than $100 \mathrm{~km})$ \\
A9 & Consumables reduction (replacement and coatings) (\%) & 0 & 100 \\
A10 & Service life & 15 & 40 \\
A11 & Extended warranty (years) & 0 & 5 \\
A12 & Facility to recovery, recuperation (especially plastics) & 0 & 100 \\
& (\%) & & 10 \\
A13 & \% shared weight with other functions & 0 & 10
\end{tabular}

The service life of the product (A10) is directly linked to the length of the warranty period (A11). We start from a default service life of 15 years, as established by Environdec (The International EPD System, 2018). We also start from a minimum guarantee length of three years in the compulsory criteria, which is in line with the European Toolkit for furniture (European Commission, 2017b). The extended guarantee in the award criteria might range between one and five years (up to eight years); therefore, the service life is lengthened considering a ratio of five years for each additional year of warranty (González-Prida, Barbera, Crespo, \& Parra, 2012), with a maximum of 40 years.

The maximum allowed weight sharing with other functions (A13) is $10 \%$ to give value to reducing the environmental impact of integrating several functions into one element. However, the complex elements of urban furniture that integrate several pieces of furniture into one should be studied in more detail. Developing this methodology to simplify data entry for the user would greatly benefit this criterion by disproportionately reducing the impacts. 


\subsection{LCA indicators}

The ReCiPe Endpoint (H) v1.13 method (Goedkoop et al., 2013) is selected, and the three endpoints, i.e., human health (HH), ecosystems (ES), and resources (R), are considered in the multi-criteria decision process with TOPSIS. These endpoints correspond to areas of protection that include the sustainability elements. Damage to human health is indicated by the disabilityadjusted loss-of-life years (DALY), the damage to ecosystem diversity is indicated by the loss of species during a year (species.yr), and the damage to resource availability is indicated by the increase in cost $(\$)$.

\subsection{Selection of elements}

Materials, which are grouped according to environmental and material properties, are the unitary elements selected to decompose all the product categories. The materials are grouped based on the results of Rydh \& Sun (2005) and the LCA performed in the LIFE FUTURE EU project. The selected groups are presented in Table 3.

Table 3. Materials groups for urban furniture

\begin{tabular}{llll}
\hline Class & Code & Material group & Material modelled \\
\hline Woods & E1 & Timber non tropical & Sawn timber, softwood \\
& E2 & Timber tropical & Sawn timber, hardwood \\
& E3 & Plywood/laminated & Plywood \\
& E4 & Particle boards & Particle board \\
\hline Metals & E5 & Ferrous & Steel unalloyed \\
& E6 & Non Ferrous & Aluminum \\
\hline Polymers \& elastomers & E7 & Thermoplastic & Polypropylene \\
& E8 & Reinforced plastic & Glass fiber reinforced plastic, polyester resin \\
& E9 & Rubber & Synthetic rubber \\
\hline Stones \& concretes & E10 & Concrete/bricks & Concrete \\
& E11 & Natural stone & Natural stone cut \\
\hline Ceramics\& glasses & E12 & Ceramic tiles & Ceramic tiles \\
& E13 & Glass & Flat glass uncoated \\
\hline Textiles & E14 & Textile & Yarn cotton \\
\hline
\end{tabular}




\begin{tabular}{llll}
\hline Packaging & E15 & Plastic not expanded & Low density polyethylene \\
& E16 & Plastic expanded & Polystyrene and foaming expanding \\
E17 & Cardboard & Corrugated board
\end{tabular}

The number of materials is the lowest possible value to ensure that they are easily identifiable by the non-experts responsible for decision-making in the GPP. Using the highest possible number of materials will reduce uncertainty, but it will also increase its difficulty of use.

\subsection{Life cycle inventories for unitary elements}

During the LIFE FUTURE EU project, different types of urban furniture were characterized based on the materials and processes used for their manufacture and the required technical specifications (LIFE FUTURE, 2015), and several life cycle inventories and their assessments were performed. All of this information is used to develop the life cycle inventories of unitary materials.

The data source is completed using Ecoinvent database v3.3 (Ecoinvent, 2016). Concerns about the quantities and characterization of the inventories are discussed below.

The life cycle inventories for the default (worst) unitary element (materials of Table 3 ) are available in the Supplementary Material, and consist of raw material (not recycled for the default option and recycled or reused for the best option), the transport of materials, energy used for production, surface treatment, maintenance, and disposal.

The method for the allocation of reuse and recycling is set according to the "recycle content method", also referred to as the "cut-off" or "100-0 output" approach (Allacker et al., 2014), consistent with ISO 14040:2006 and ISO 14044:2006. This approach is adopted by Environdec (The International EPD System, 2012) and BIFMA (NSF International National Center for Sustainability Standards, 2014) in their current frameworks of product category rules for 
furniture. If there is an inflow of recycled materials to the production system, the recycling process and transportation from recycling to the site at which the material is used is included.

Three options are considered for transportation: local transport for distances of or less than 100 $\mathrm{km}$, transportation inside Europe, and transportation outside Europe. Local transportation is assumed to be by road with a distance of $100 \mathrm{~km}$. The mean distance for each material inside Europe is derived from the Eurostat data for road and rail in annual tons and annual tons-km (Eurostat, 2017, 2018). As the Eurostat data are for loaded vehicles, a ratio is applied to also consider empty vehicles - in 2015, 23\% of all vehicle-km by heavy goods vehicles in the EU were empty runs (European Commission, 2017a). The mean distance by road and rail is increased by $16500 \mathrm{~km}$ for maritime transport of materials from outside Europe. An average European fleet of lorries heavier than $16 \mathrm{t}$ is considered for transport from the manufacturing to the construction site, and for the transport of materials (Ecoinvent, 2016). An average load of $9.51 \mathrm{t}$ is estimated as the default state. For the best option, the volume reduction (award criterion, A4) is calculated assuming an increase in the average load to $10.46 \mathrm{t}$.

The main energy utilized in production is electricity (estimated as the medium voltage at the grid/RER from Ecoinvent database v 3.3). Approximately $8.8 \%$ of this electricity is produced from renewable sources. Higher percentages of renewables energies are considered for awareness (award criterion, A5). For the best option, electricity is obtained entirely from renewable sources (estimated as wind power/RER from the Ecoinvent database v 3.3) and with a reduction of $20 \%$ from the default amount (award criterion A6). Diesel is another considered energy type. For the best option, the same considerations as electricity are applied. The energy consumption for 
production is mainly obtained from Ecoinvent database v 3.3, and electricity for processing plastic materials is obtained from the Recipe project (RECIPE, 2005).

Surface treatment is estimated considering the standard value of the industrial sector. The default surface treatment includes preservative treatment with organic salts and varnish for wood, zin coating for steel, anodizing for aluminum, and paint for metals.

Maintenance is estimated considering the standard value of the industrial sector. The default consumables consumption includes annual varnishing for wood and painting every five years for metals. Maintenance is not included in the best option. Other consumables, such as small pieces that may need to be replaced during the lifetime of the product are included in the whole product.

All materials are supposed to be landfilled at the end of their life. Award criterion A12 is only applied to thermoplastic materials.

Three materials are considered for packaging: non-expanded plastic (modeled as LDPE granulate), expanded plastic (modeled as polystyrene expandable and foaming expanding), and corrugated board. The electricity for processing is obtained from the Recipe project (RECIPE, 2005). The default modeled materials are virgin materials transported from outside of Europe. The remaining materials are awarded with recycling and transport reduction (Award A8a \& A8b in Table 2). Packaging requires a special treatment for scoring (see section 3.8).

\subsection{Life cycle assessments of unitary elements}

LCAs of the default and best unitary elements are available in the Supplementary Material and the ranges of the best and worst values for each material are shown in Figure 3. 

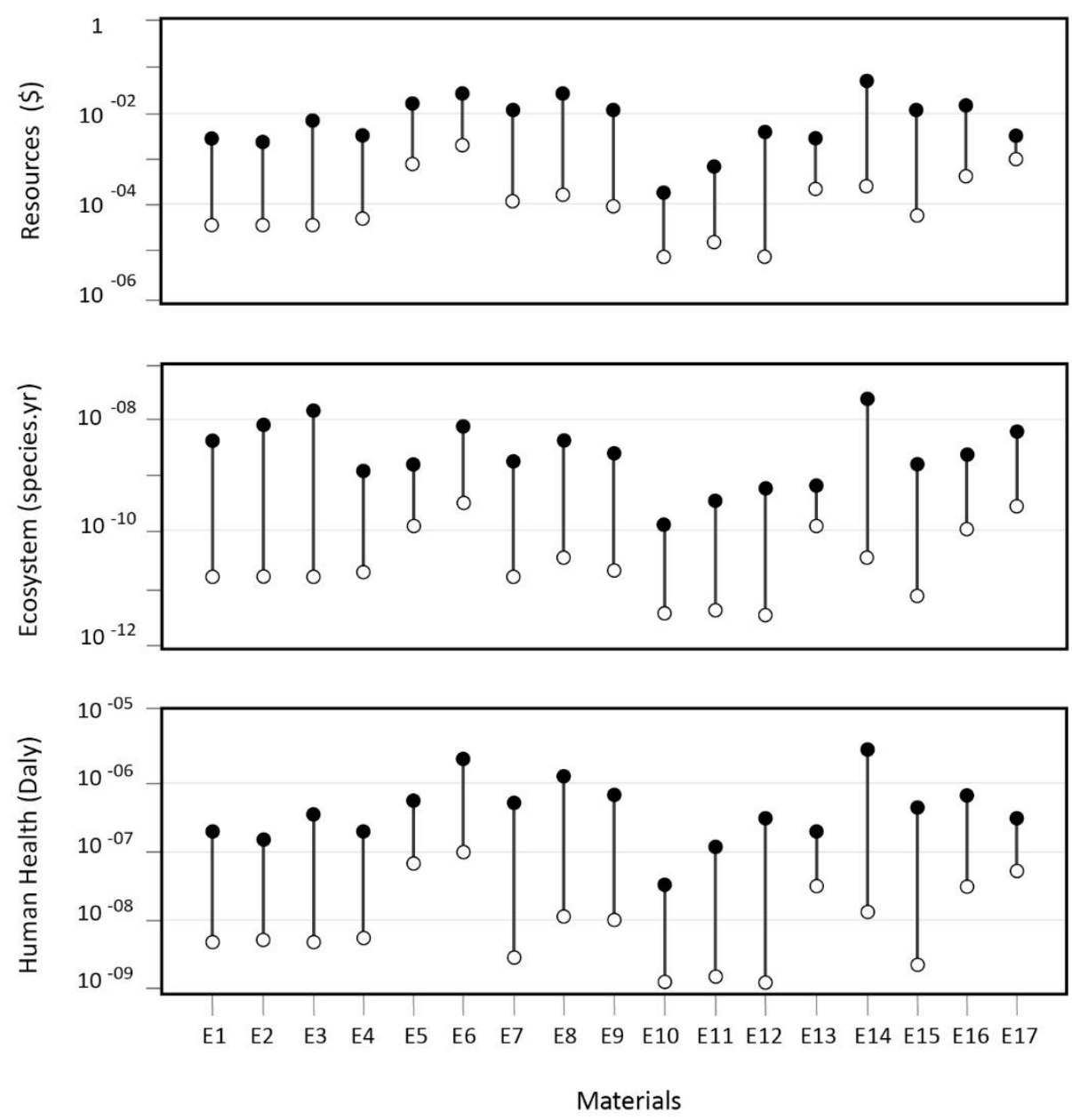

Figure 3. LCA of the best and default unitary materials $(1 \mathrm{~kg})$. Black points are the default values and hollow points are the best values for each material. Materials codes are detailed in Table 3.

\subsection{Life cycle assessments}

The three endpoints $(\mathrm{HH}, \mathrm{ES}$, and $\mathrm{R})$ are obtained from the LCAs of unitary elements and the amount of each element in the product. 


\subsection{Scoring}

Scoring is obtained by applying the TOPSIS technique to all materials in the product $\left(\mathrm{x}_{\mathrm{i}}\right)$ except their packaging. The three endpoints are used to replace $m$ in equation (1), and equation (2) is derived in equation (3):

$$
x_{i}=\frac{100}{\sqrt{3}} \cdot \sqrt{\frac{\left(x_{i H H}-x_{i H H}^{-}\right)^{2}}{\left(x_{i H H}^{+}-x_{i H H}^{-}\right)^{2}}+\frac{\left(x_{i E S}-x_{i E S}^{-}\right)^{2}}{\left(x_{i E S}^{+}-x_{i E S}^{-}\right)^{2}}+\frac{\left(x_{i R}-x_{i R}^{-}\right)^{2}}{\left(x_{i R}^{+}-x_{i R}^{-}\right)^{2}}}
$$

Packaging $\left(x_{p}\right)$ reduces the score obtained using equation (3). Note that the award criteria for packaging diminish the reduction of the worst alternative packaging option:

$$
x_{p}=\frac{100}{\sqrt{3}} \cdot\left(\sqrt{\frac{\left(x_{p H H}-x_{p H H}^{-}\right)^{2}}{\left(x_{i H H}^{+}-x_{i H H}^{-}\right)^{2}}+\frac{\left(x_{p E S}-x_{p E S}^{-}\right)^{2}}{\left(x_{i E S}^{+}-x_{i E S}^{-}\right)^{2}}+\frac{\left(x_{p R}-x_{p R}^{-}\right)^{2}}{\left(x_{i R}^{+}-x_{i R}^{-}\right)^{2}}}-\sqrt{\frac{\left(x_{p H H}^{-}\right)^{2}}{\left(x_{i H H}^{+}-x_{i H H}^{-}\right)^{2}}+\frac{\left(x_{p E S}^{-}\right)^{2}}{\left(x_{i E S}^{+}-x_{i E S}^{-}\right)^{2}}+\frac{\left(x_{p R}^{-}\right)^{2}}{\left(x_{i R}^{+}-x_{i R}^{-}\right)^{2}}}\right)
$$

The final result is obtained with the restriction that the minimum score value is zero:

$$
x=\max \left(x_{i}+x_{p}, 0\right)
$$

\subsection{Ranking products}

Table 4 presents an example of the GPP of benches with three simulated bids to illustrate the use of the method and the result of ranking. In a real application, tenderers would provide all data. In this example, five award criteria and three different materials are considered. Bids A and $B$ are benches with steel frames and a plastic seat and backrest. Both have different weights and recycling rates for plastic, Bid A has a low recycling rate, and bid $\mathrm{B}$ is composed entirely of recycled plastic. Bid C is a bench with a steel frame and a tropical wooden seat. This bench has a longer 
service life and an extended warranty of one year. All three benches have the same steel recycling rate, which is the rounded average value for steel produced in Spain (BIR, 2017). The result of equation (3) is presented in the 'Environmental score' row and indicates that bid B is the most environmental option with 54.5 points.

Table 4. Example of environmental scoring and ranking of benches. Values are for one bench.

\begin{tabular}{lcccc}
\hline & Award & Bid A & Bid B & Bid C \\
\hline E2, Timber tropical, kg & & 0 & 0 & 20 \\
E5, Ferrous, kg (\% recycled) & A1 & $30(70 \%)$ & $40(70 \%)$ & $90(70 \%)$ \\
E7, Thermoplastic, kg (\% recycled) & A1 & $40(20 \%)$ & $25(100 \%)$ & 0 \\
\% Renewable energy & A5 & 0 & 30 & \\
Distance manufacturing-construction site, km & A7 & 700 & 500 & 1000 \\
Service life, years (extended warranty) & A10 (A11) & 15 & 15 & $20(1)$ \\
\hline Environmental score, points & & 28.5 & 54.5 & 52.0 \\
\hline Price, $€$ & & 250 & 270 & 300 \\
\hline Price score, points & & 100 & 92 & 80 \\
\hline Total, points (ranking) & $\mathbf{7 8 . 6 ( 2 )}$ & $\mathbf{8 0 . 8 ( 1 )}$ & $\mathbf{7 1 . 6 ( 3 )}$ \\
\hline
\end{tabular}

In this fictive procurement process, the environmental criteria receive $30 \%$ of the total points. The remaining points are for the price, giving the highest price score to the bid with the lowest price. The remaining bids are scored using equation (6):

$$
\text { Price scoring }=100-\left(\frac{\text { Price }- \text { Lowest price }}{\text { Lowest price }}\right) \cdot 100
$$

Bid $A$ has the lowest price. If environmental criteria were not considered, bid $A$ would be selected. However, as this example considers environmental criteria in the award, bid B has the highest total score, and would be the option selected.

\section{Discussion}

Implementing GPP is not a simple task (Cheng et al., 2018). Therefore, it is advisable to incorporate appropriate and available environmental tools with decision-making tools. The 
simplified data entry of the methodology presented in this paper provides the usability required for a standardized public procurement process. Award criteria and knowledge of GPP techniques are promoted, which are the factors that were identified by Testa et al. (2016) as the most relevant for the implementation and development of GPP practices by public administrations. The results of the case study and several topics of the method are discussed below.

\subsection{Range of the award criteria in the case study}

In the case study of urban furniture, the range of scoring for each award criterion is studied for each material except for their packaging. The minimum value for each award criterion is zero and the maximum value is the highest fixed threshold of the criterion being studied. The remaining award criteria are fixed to their lowest threshold (Table 2). In all cases, one kilogram of one material is considered without packaging.

Award criteria have different significances for scoring. The highest and lowest scores are represented for each award criterion in Figure 4. Note that award criteria A10 and A11 are activated together because they are assumed to be related. Some scores are missing for A1 because recycling is not considered (E8, E12) or it is included as the default option (E3, E4). Award criteria A1 (recycling) and A10-A11 (service life \& extended warranty) are the most significant for environmentally sustainable urban furniture, followed by $A 7$ (transport of the product) and A5 (renewable energy). However, A12 (facility to recover plastics) and A4 (volume reduction) are the least significant criteria for environmentally sustainable urban furniture. 


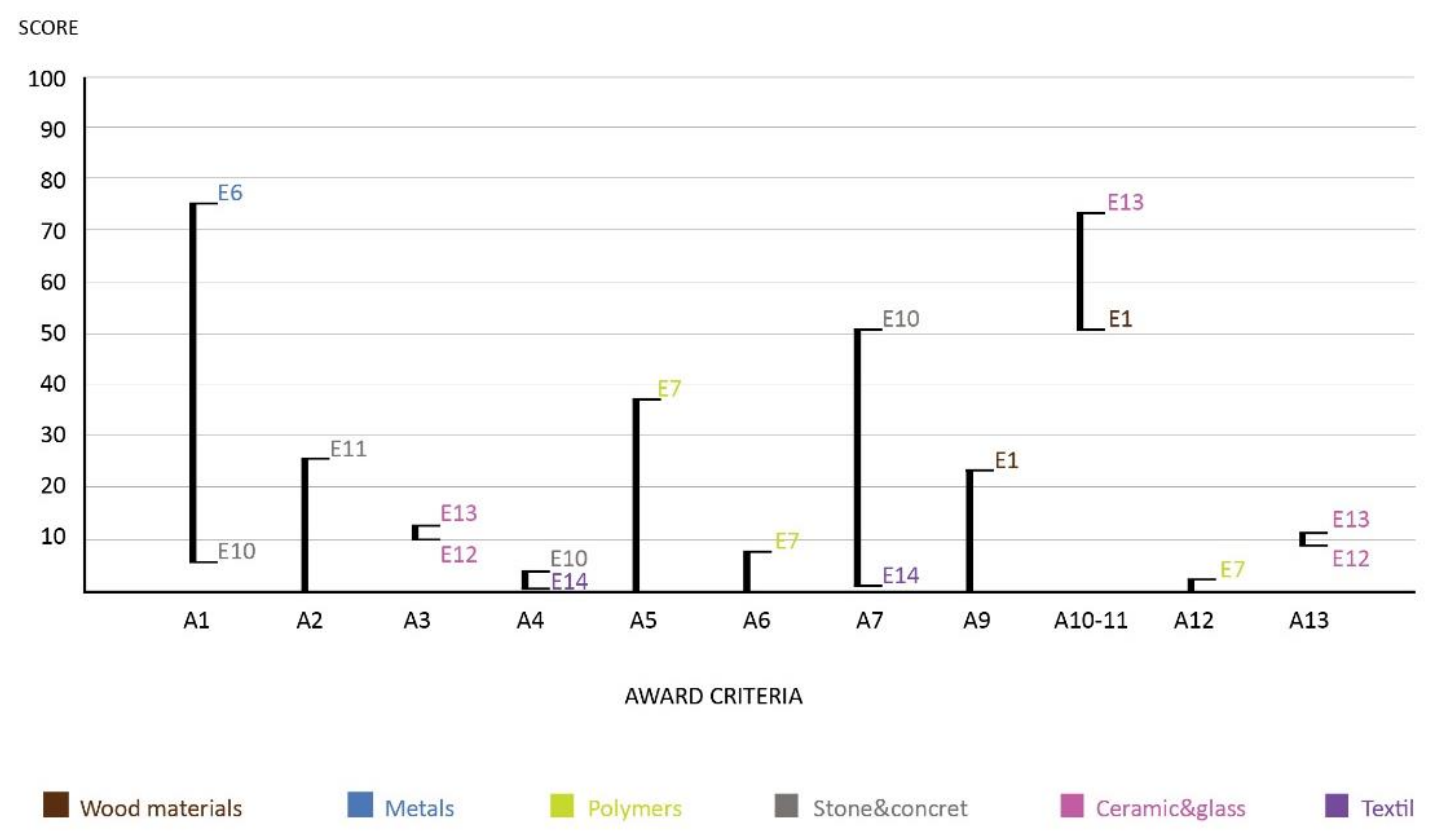

Figure 4. Scoring range for maximum values of award criteria

\subsection{Other award criteria}

Cost, aesthetic, and market availability are some of the other criteria that have not been included in the methodology, and will influence the selection of materials and the degree of effort required by the selected eco-design strategies, affecting the final score.

The method could be updated to include price and also other criteria. In the case study presented in section 3, equation (3) could be modified to equation ( 7 ) if a new dimension, i.e., the price, is added to the three preexisting environmental dimensions. In equation (7), $\mathrm{M}$ is the sum of the individual weights for human health $(H)$, ecosystems $(S)$, resources $(R)$, and price $(P)$.

$$
x_{i}=\frac{100}{\sqrt{M}} \cdot \sqrt{\frac{H \cdot\left(x_{i H H}-x_{i H H}^{-}\right)^{2}}{\left(x_{i H H}^{+}-x_{i H H}^{-}\right)^{2}}+\frac{S \cdot\left(x_{i E S}-x_{i E S}^{-}\right)^{2}}{\left(x_{i E S}^{+}-x_{i E S}^{-}\right)^{2}}+\frac{R \cdot\left(x_{i R}-x_{i R}^{-}\right)^{2}}{\left(x_{i R}^{+}-x_{i R}^{-}\right)^{2}}+\frac{P \cdot\left(x_{i P}-x_{i P}^{-}\right)^{2}}{\left(x_{i P}^{+}-x_{i P}^{-}\right)^{2}}}
$$


In this paper, all considered dimensions are equally weighted because the interest is in the distance to the best option. Other weighting schemas are possible, such as various cultural perspectives (Kalbar et al., 2016). In that case, equation (3) would be modified in a similar way to equation (7), including the weights of each of the dimensions considered.

\subsection{Life cycle cost}

At the award stage of a procurement procedure, the cost of a tender is usually one of the most influential factors. By applying life-cycle cost (LCC) in addition to the purchase price and all associated costs (including delivery, installation, and insurance), the costs of resource use, operating costs, maintenance, and disposal, which are not reflected in the purchase price, are considered. LCC may also include the cost of externalities (EU, 2014). In this case, the environmental costs identified by LCA must be monetized. However, the transition to convert environmental impact figures into monetized measures is not always simple (Hoogmartens, Van Passel, Van Acker, \& Dubois, 2014). The use of LCC within GPP practices has rarely been explored (De Giacomo, Testa, Iraldo, \& Formentini, 2018). Therefore, LCC is not included. Some experimentation is required to determine how complementary LCC and LCA studies can effectively inform decision-making by multiple stakeholders with differing and potentially conflicting perspectives and goals (Swarr et al., 2011).

\subsection{Recommendations in the selection of materials}

The EU GPP criteria are developed to facilitate the inclusion of green requirements in public tender documents. While the adopted EU GPP criteria aim to achieve a good balance between environmental performance, cost considerations, market availability, and ease of verification, 
procuring authorities may choose to include all or only certain requirements in their tender documents according to their needs and ambition level (European Commission, 2017b), excluding specific recommendation or prohibitions for generic materials. The same objective is followed in this new methodology based on the distance to the best environmentally sustainable option, although the relevance of each award criterion is dependent on the material (Figure 4) and, in the case of products with multiple materials, each will make different contributions to estimate the distance and the final score (see Figure 3 and equation 3).

\subsection{Midpoints or endpoints}

In this paper, TOPSIS is applied to the endpoints obtained from the ReCiPe method, although our methodology is equally applicable with the midpoints of impact categories or other LCA methods, as step three of the methodology is open to different impact indicators. The use of midpoint impact categories would reduce the uncertainty. However, this would require an increase in programming effort. The main uncertainty is the simplification of the unitary elements, which is required to guarantee usability by public authorities. The use of midpoint impact categories would have no effect on this.

\subsection{Limitations}

Simplified and predefined inventories of elements are one of the key elements to facilitate environmental assessments for GPP practitioners (step 5), although environmental assessments using them are less accurate. 
The unitary elements must be defined for each product group, and their inventories are conditioned by the current situation and the award criteria to be considered (step 1). The adoption of other technologies, materials, or changes in award criteria would require changes to the inventories of unitary elements.

Currently, the method has only been developed and applied to street furniture products, and does not include elements that require energy for their use.

The verification of environmental criteria requires tenderers to provide information to public authorities. A lot of this information is missing from product data sheets and environmental declarations. The LIFE FUTURE project has emphasized the provision of template declarations to facilitate the transmission of information. A lack of information may lead to the elimination of a bid or to a lower score.

If it is important for tenderers to be involved in GPP, the involvement of public authorities is just as important. It is up to public authorities to decide whether the tendering process only considers the lowest price offer or whether other award criteria are considered.

\subsection{Future scope}

GUF TOOL was designed and tested during the LIFE FUTURE project for urban furniture. The methodology, as explained in section 2, could be applied to any other GPP category (such as energy, cleaning products, or food), including products with energy consumption. Each new product category will require the selection of compulsory and award criteria, those with threshold limits, and unitary elements to decompose the product categories. These unitary elements will 
be defined in three alternatives: the worst, the best, and the highest bidder, and their inventory and life cycle assessment will be then performed.

The use of life cycle cost within GPP and the complementarity between external costs and LCA are interesting research topics. Undoubtedly, the incorporation of environmental assessments, life cycle costing and social considerations would extend this method to be suitable for sustainable public procurement (Walker, Miemczyk, Johnsen, \& Spencer, 2012).

\section{Conclusions}

A new method for assessing environmental award criteria in GPP processes is introduced to integrate environmental criteria into public tenders, and provide easy and effective communication of the environmental benefits of the products and services purchased.

The method is intended for use by public authorities and companies; therefore, usability is a key factor. The input data must be simplified to ensure their usability, even if this makes environmental assessment less precise.

Environmental endpoint indicators are estimated through a simplified life cycle assessment that uses pre-defined life cycle inventories for a small number of selected unitary elements of the product categories to be assessed. Inventories are internally derived with the default, best, and bidder options, and the award criteria values of these vary.

LCA provides the environmental profile of each bid using several indicators. However, this is not convenient for ranking, and environmental indicators are simplified to one score using TOPSIS. 
This method was developed and applied for GPP of urban furniture. Therefore, the compulsory and award criteria were defined for urban furniture, in addition to the life cycle inventories of the selected unitary elements. Recycling and extended warranty-service life are the most significant award criteria for this case.

This new method fills the existing gap for integrating environmental award criteria into public procurement. The proposed method is initially applied in an online application for urban furniture, although other product categories could benefit once award criteria and unit elements to decompose them were defined.

\section{Acknowledgements}

Authors gratefully appreciate the financial support of the LIFE financial instrument of the European Union for the project LIFE FUTURE (LIFE14 ENV/ES/000703). We greatly acknowledge Nuria Vernís for her contribution in the design of the figures of this manuscript.

\section{References}

AhIroth, S., Nilsson, M., Finnveden, G., Hjelm, O., \& Hochschorner, E. (2011). Weighting and valuation in selected environmental systems analysis tools e suggestions for further developments. Journal of Cleaner Production, 19, 145-156. https://doi.org/10.1016/j.jclepro.2010.04.016

Allacker, K., Mathieux, F., Manfredi, S., Pelletier, N., De Camillis, C., Ardente, F., \& Pant, R. (2014). Allocation solutions for secondary material production and end of life recovery: Proposals for product policy initiatives. Resources, Conservation and Recycling, 88, 1-12. https://doi.org/10.1016/J.RESCONREC.2014.03.016

Amine, M. El, Pailhes, J., \& Perry, N. (2014). Critical Review of Multi-criteria Decision Aid Methods in Conceptual Design Phases: Application to the Development of a Solar Collector Structure. Procedia CIRP, 21, 497-502. https://doi.org/10.1016/J.PROCIR.2014.03.134

Bare, J. C. (2002). The tool for the reduction and assessment of chemical and other environmental impacts. Journal of Industrial Ecology, 6(3-4), 49-78. https://doi.org/10.1162/108819802766269539

Bratt, C., Hallstedt, S., Robèrt, K.-H., Broman, G., \& Oldmark, J. (2013). Assessment of criteria development for public procurement from a strategic sustainability perspective. Journal of Cleaner Production, 52, 309-316. https://doi.org/10.1016/j.jclepro.2013.02.007 
Brezet, J. C., \& Hemel, C. van. (1997). Ecodesign: a promising approach to sustainable production and consumption (1st ed). Paris: UNEP.

Castellani, V., Benini, L., Sala, S., \& Pant, R. (2016). A distance-to-target weighting method for Europe 2020. The International Journal of Life Cycle Assessment, 21(8), 1159-1169. https://doi.org/10.1007/s11367-016-1079-8

Cerutti, A. K., Contu, S., Ardente, F., Donno, D., \& Beccaro, G. L. (2016). Carbon footprint in green public procurement: Policy evaluation from a case study in the food sector. Food Policy, 58, 82-93. https://doi.org/10.1016/j.foodpol.2015.12.001

Cheng, W., Appolloni, A., D’Amato, A., \& Zhu, Q. (2018). Green Public Procurement, missing concepts and future trends - A critical review. Journal of Cleaner Production, 176, 770-784. https://doi.org/10.1016/J.JCLEPRO.2017.12.027

Chulvi, V., \& Vidal, R. (2011). Usefulness of evolution lines in eco-design. In Procedia Engineering (Vol. 9, pp. 135-144).

Cordella, M., \& Hidalgo, C. (2016). Analysis of key environmental areas in the design and labelling of furniture products: Application of a screening approach based on a literature review of LCA studies. Sustainable Production and Consumption, 8, 64-77. https://doi.org/10.1016/J.SPC.2016.07.002

De Giacomo, M. R., Testa, F., Iraldo, F., \& Formentini, M. (2018, May 23). Does Green Public Procurement lead to Life Cycle Costing (LCC) adoption? Journal of Purchasing and Supply Management. https://doi.org/10.1016/j.pursup.2018.05.001

Deakin, M., \& Reid, A. (2014). Sustainable urban development: Use of the environmental assessment methods. Sustainable Cities and Society, 10, 39-48. https://doi.org/10.1016/j.scs.2013.04.002

Doan, D. T., Ghaffarianhoseini, A., Naismith, N., Zhang, T., Ghaffarianhoseini, A., \& Tookey, J. (2017, October 1). A critical comparison of green building rating systems. Building and Environment. Pergamon. https://doi.org/10.1016/j.buildenv.2017.07.007

Ecoinvent. (2016). Ecoinvent Data v3.3. The ecoinvent Association.

EU. Directive 2014/24/EU of the European Parliament and of the Council of 26 February 2014 on public procurement and repealing Directive 2004/18/EC Text with EEA relevance, Pub. L. No. 2014/24/EU, Official Journal of the European Union (2014).

European Comission. (2016). Buying green! A handbook on green public procurement (3rd ed.). https://doi.org/10.2779/246106

European Commission. (2017a). An Overview of the EU Road Transport Market in 2015.

European Commission. (2017b). EU Green Public criteria for Furniture - GPP - Environment. Retrieved February 27, 2018, from http://ec.europa.eu/environment/gpp/eu_gpp_criteria_en.htm

Eurostat. (2017). Railway transport - goods transported, by group of goods - from 2008 onwards based on NST 2007 (1 000 t, million tkm) [rail_go_grpgood] Last update: 30-11-2017. Retrieved February 22, 2018, from http://appsso.eurostat.ec.europa.eu/nui/show.do?dataset=rail_go_grpgood\&lang=en

Eurostat. (2018). Annual road freight transport, by type of goods and type of transport (1000 t, Mio Tkm), from 2008 onwards. Retrieved February 22, 2018, from http://appsso.eurostat.ec.europa.eu/nui/show.do?dataset=road_go_ta_tg\&lang=en

Fenner, R. A., \& Ryce, T. (2008). A comparative analysis of two building rating systems Part 1: Evaluation. Proceedings of the Institution of Civil Engineers - Engineering Sustainability, 161(1), 55-63. 
https://doi.org/10.1680/ensu.2008.161.1.55

Frischknecht, R., Steiner, R., \& Jungbluth, N. (2009). The Ecological Scarcity Method-Eco-Factors 2006. A method for impact assessment in LCA. Environmental Studies No. 0906. https://doi.org/citeulikearticle-id:12461602

Goedkoop, M., Heijungs, R., De Schryver, A., Struijs, J., \& van Zelm, R. (2013). ReCiPe 2008. A LCIA method which comprises harmonised category indicators at the midpoint and the endpoint level. Characterisation. https://doi.org/http://www.lcia-recipe.net

González-Prida, V., Barbera, L., Crespo, A., \& Parra, C. (2012). Cálculo del período de garantía tras la reparación de un activo industrial complejo, aplicando procesos de poisson no homogéneos. DYNA Ingeniería e Industria, 87(3), 655-662. https://doi.org/10.6036/4965

Gowri, K. (2005). Desktop Tools For Sustainable Design. ASHRAE Journal, 47(January), 42-46.

Grove, A., \& Cresswell, R. (1983). City landscape: a contribution ot the Council of Europe's European Campaign for Urban Renaissance. Butterworth-Heinemann.

Hafizan, C., Noor, Z. Z., Abba, A. H., \& Hussein, N. (2016). An alternative aggregation method for a life cycle impact assessment using an analytical hierarchy process. Journal of Cleaner Production, 112, 32443255. https://doi.org/10.1016/j.jclepro.2015.09.140

Hoogmartens, R., Van Passel, S., Van Acker, K., \& Dubois, M. (2014). Bridging the gap between LCA, LCC and CBA as sustainability assessment tools. Environmental Impact Assessment Review, 48, 27-33. https://doi.org/10.1016/J.EIAR.2014.05.001

Huang, I. B., Keisler, J., \& Linkov, I. (2011). Multi-criteria decision analysis in environmental sciences: Ten years of applications and trends. Science of The Total Environment, 409(19), 3578-3594. https://doi.org/10.1016/J.SCITOTENV.2011.06.022

Huppes, G., van Oers, L., Pretato, U., \& Pennington, D. W. (2012). Weighting environmental effects: Analytic survey with operational evaluation methods and a meta-method. The International Journal of Life Cycle Assessment, 17(7), 876-891. https://doi.org/10.1007/s11367-012-0415-x

Hwang, C.-L., \& Yoon, K. (1981). Methods for Multiple Attribute Decision Making (pp. 58-191). Springer, Berlin, Heidelberg. https://doi.org/10.1007/978-3-642-48318-9_3

ICLEI. (2013). Buying Sustainable Timber. A guide for public purchaser in Europe.

IHOBE. (2014). Manual práctico de compra y contratación pública verde.

ISO, E. (2006). Environmental management. Life cycle assessment. Requierements and guidelines (14044: 2006). European Comittee for Standarization.

Kägi, T., Dinkel, F., Frischknecht, R., Humbert, S., Lindberg, J., De Mester, S., ... Schenker, U. W. (2016). Session "Midpoint, endpoint or single score for decision-making?" -SETAC Europe 25th Annual Meeting, May 5th, 2015. The International Journal of Life Cycle Assessment, 21(1), 129-132. https://doi.org/10.1007/s11367-015-0998-0

Kalbar, P. P., Birkved, M., Nygaard, S. E., \& Hauschild, M. (2016). Weighting and Aggregation in Life Cycle Assessment: Do Present Aggregated Single Scores Provide Correct Decision Support? Journal of Industrial Ecology. https://doi.org/10.1111/jiec.12520

Kylili, A., \& Fokaides, P. A. (2017, November 1). Policy trends for the sustainability assessment of construction materials: A review. Sustainable Cities and Society. Elsevier. https://doi.org/10.1016/j.scs.2017.08.013 
LIFE FUTURE. (2015). D1.2 Report on the selected products and their specifications (technical description). Retrieved from http://www.life-future-project.eu/dissemination.php?op=4

LIFE FUTURE. (2018). HOME GUF TOOL Life Future Project. Retrieved March 9, 2018, from http://lifefuture.uji.es/

Lippiatt, B. C. (1999). Selecting Cost-Effective Green Building Products: BEES Approach. Journal of Construction Engineering and Management, 125(6), 448-455. https://doi.org/10.1061/(ASCE)07339364(1999)125:6(448)

Lundberg, S., \& Marklund, P.-O. (2012). Green Public Procurement as an Environmental Policy Instrument:Cost Effectiveness. Umeå Economic Studies.

Lundberg, S., \& Marklund, P.-O. (2018). Green public procurement and multiple environmental objectives. Economia e Politica Industriale, 45(1), 37-53. https://doi.org/10.1007/s40812-017-0085-6

Mattinen, M. K., \& Nissinen, A. (2012). Carbon Footprint Calculators for Public Procurement of Six Product Groups. In Carbon Footprint Calculators for Public Procurement of Six Product Groups. https://doi.org/10.6027/TN2017-548

Myllyviita, T., Leskinen, P., \& Seppälä, J. (2014). Impact of normalisation, elicitation technique and background information on panel weighting results in life cycle assessment. The International Journal of Life Cycle Assessment, 19(2), 377-386. https://doi.org/10.1007/s11367-013-0645-6

NSF International National Center for Sustainability Standards. (2014). Product Category Rule for Environmental Product Declaration. BIFMA PCR for Seating: UNCPC 3811 Version 3. Valid through September 30, 2019.

Parikka-Alhola, K., \& Nissinen, A. (2012). Environmental impacts and the most economically adventageous tender on public procurement. Journal of Public Procurement, 12(1), 43-80.

Paryabi, A. (2015). Organizing and tailoring of urban furniture. Cumhuriyet Science Journal, 36(4), 9981012. https://doi.org/10.17776/CSJ.04282

Pianoo. (2015). Environmental criteria for sustainable public procurement of Outdoor Furniture.

Pizzol, M., Laurent, A., Sala, S., Weidema, B., Verones, F., \& Koffler, C. (2017). Normalisation and weighting in life cycle assessment: quo vadis? The International Journal of Life Cycle Assessment, 22(6), 853866. https://doi.org/10.1007/s11367-016-1199-1

Rainville, A. (2017). Standards in green public procurement - A framework to enhance innovation. Journal of Cleaner Production, 167, 1029-1037. https://doi.org/10.1016/J.JCLEPRO.2016.10.088

RECIPE. (2005). 2005 European benchmarking survey of energy consumption and adoption of best practice.

Rossi, M., Germani, M., \& Zamagni, A. (2016, August 15). Review of ecodesign methods and tools. Barriers and strategies for an effective implementation in industrial companies. Journal of Cleaner Production. Elsevier. https://doi.org/10.1016/j.jclepro.2016.04.051

Rousseaux, P., Gremy-Gros, C., Bonnin, M., Henriel-Ricordel, C., Bernard, P., Floury, L., ... Vincent, P. (2017). "Eco-tool-seeker"A new and unique business guide for choosing ecodesign tools. Journal of Cleaner Production, 151, 546-577. https://doi.org/10.1016/j.jclepro.2017.03.089

Rydh, C. J., \& Sun, M. (2005). Life cycle inventory data for materials grouped according to environmental and material properties. Journal of Cleaner Production, 13(13-14), 1258-1268. https://doi.org/10.1016/j.jclepro.2005.05.012 
Saaty, T. L. (1990). How to make a decision: The analytic hierarchy process. European Journal of Operational Research, 48(1), 9-26. https://doi.org/10.1016/0377-2217(90)90057-I

Salmeron, J. L., Vidal, R., \& Mena, A. (2012). Ranking fuzzy cognitive map based scenarios with TOPSIS. Expert Systems with Applications, 39(3), 2443-2450. https://doi.org/10.1016/j.eswa.2011.08.094

Seppälä, J., Basson, L., \& Norris, G. A. (2001). Decision Analysis Frameworks for Life-Cycle Impact Assessment. Journal of Industrial Ecology, 5(4), 45-68. https://doi.org/10.1162/10881980160084033

Swarr, T. E., Hunkeler, D., Klöpffer, W., Pesonen, H.-L., Ciroth, A., Brent, A. C., \& Pagan, R. (2011). Environmental life-cycle costing: a code of practice. The International Journal of Life Cycle Assessment, 16(5), 389-391. https://doi.org/10.1007/s11367-011-0287-5

Testa, F., Annunziata, E., Iraldo, F., \& Frey, M. (2016). Drawbacks and opportunities of green public procurement: an effective tool for sustainable production. Journal of Cleaner Production, 112, 18931900. https://doi.org/10.1016/J.JCLEPRO.2014.09.092

The International EPD System. (2012). Product Category Rules in accordance with ISO 14025:2006. Version 1.1 PCR 2012:19. Product Group UN CPC 3812 \& 3814 Other Furniture Used in Offices and Other Furniture N. E. C. Version 1.2 Valid until 2018-12-14.

The International EPD System. (2018). Product Category Rules in accordance with ISO 14025:2006. Version 1.2 PCR 2012:19 Other furniture used in offices and other furniture N.E.C.

Trop, T. (2018). Using Envision ${ }^{\mathrm{TM}}$ rating tool to assess the sustainability of public bike sharing systems: A case study of the Tel-O-Fun project in Tel Aviv-Yafo. Sustainable Cities and Society, 40, 704-712. https://doi.org/10.1016/j.scs.2017.11.040

Umweltbundesamt. (2013). Guide to green public procurement of wood furniture.

US EPA, O. (2016). Comprehensive Procurement Guidelines for Non-Paper Office Products.

Vidal, R., Salmeron, J. L., Mena, A., \& Chulvi, V. (2015). Fuzzy Cognitive Map-based selection of TRIZ trends for eco-innovation of ceramic industry products. Journal of Cleaner Production, 107(16), 202-214. https://doi.org/10.1016/j.jclepro.2015.04.131

Walker, H., Miemczyk, J., Johnsen, T., \& Spencer, R. (2012, December 1). Sustainable procurement: Past, present and future. Journal of Purchasing and Supply Management, 18(4), 201-206. https://doi.org/10.1016/j.pursup.2012.11.003

Wenzel, H., \& Hauschild, M. Z. (1998). Environmental Assessment of Products: Volume 2: Scientific Background. Environmental Assessment of Products. Chapman \& Hall. 